\title{
Taurine supplementation in diet for olive flounder at low water temperature
}

\author{
Joo-Min Kim², G. H. T. Malintha², G. L. B. E. Gunathilaka², Chorong Lee², Min-Gi Kim², Bong-Joo Lee², \\ Jeong-Dae Kim ${ }^{4}$ and Kyeong-Jun Lee ${ }^{2^{*}}$
}

\begin{abstract}
The objective of this study was to examine the effect of dietary supplementation of taurine for juvenile olive flounder (Paralichthys olivaceus) at low water temperature $\left(16.4 \pm 0.36^{\circ} \mathrm{C}\right)$. Fish meal (FM)-based diet was used as the control diet. Four other experimental diets were prepared by adding taurine to FM-based diet at 0.25, 0.50, 1.00, and 1 . $50 \%$ (T1, T2, T3, and T4, respectively). Each experimental diet was fed to triplicate groups of fish (initial mean body weight, $19.5 \mathrm{~g}$ ) for 10 weeks. At the end of the feeding trial, growth performance and feed utilization, hematological parameters, non-specific immune responses, whole-body proximate composition, and liver mRNA expression of insulin-like growth factor-1 (IGF-1) were investigated. Feed conversion ratio was significantly reduced while protein efficiency ratio was significantly increased in taurine-supplemented groups. Hematocrit and hemoglobin were also significantly increased while plasma cholesterol levels were decreased in taurine-supplemented groups than those in the control group. Nitroblue-tetrazolium, myeloperoxidase and lysozyme activities, and plasma immunoglobulin level were significantly increased by taurine supplementation. These results suggest that dietary taurine supplementation is effective in improving growth performances, feed utilization, and innate immunity of olive flounder in low water temperature season.
\end{abstract}

Keywords: Taurine, Olive flounder, Innate immunity, Water temperature

\section{Background}

Taurine (2-aminoethane sulfonic acid) is an amino acid synthesized from methionine via cysteine by a series of enzymatic reactions (Oja and Kontro 1983). It is considered as a conditionally indispensable amino acid for marine or cold water fish species. The ability of fish to synthesize taurine is species or developmental stage dependent (Yokoyama et al. 2001; Kim et al. 2003, 2005). The reason for such differences in their ability to synthesize taurine might be due to various activities of L-cysteine sulfinate decarboxylase, an enzyme required for the conversion from cysteine to taurine (De la Rosa and Stipanuk 1985; Takeuchi et al. 2001; Yokoyama et al. 2001). Although taurine is nonessential, its inclusion in diets is often recommended because of its auxiliary actions such as membrane protection, antioxidation and detoxification in mammals (Wright et al. 1986). In addition, it plays a role in osmoregulation in invertebrates (Schaffer et al. 2000), acts as a carrier for lipid-soluble vitamins in mammals (Petrosian and

\footnotetext{
* Correspondence: kjlee@jejunu.ac.kr

${ }^{2}$ Department of Marine Life Sciences, Jeju National University, Jeju 63243,

South Korea

Full list of author information is available at the end of the article
}

Haroutounian 2000) and induces bile salt production in fish (Van Waarde 1988). Due to its unique amino acid properties (i.e. low molecular weight, nitrogen content and water solubility), taurine can also act as a feed stimulant for fish (Carr 1982). It has been reported that taurine is effective as a feed attractant by stimulating the olfactory system of arctic char (Salvelinus alpinus), grayling (Thymallus thymallus) (Doving et al. 1980) and rainbow trout (Oncorhynchus mykiss) (Hara et al. 1984).

Effects of water temperature on nutrient utilization have been studied in many fish species (Olsen and Ringn 1998; Peres and Oliva-Teles 1999). It has been reported that the optimum temperature for growth of Japanese flounder is $20-25{ }^{\circ} \mathrm{C}$, even though they can be fed at low temperatures ranging from 10 to $20{ }^{\circ} \mathrm{C}$ (Iwata et al. 1994). In most studies, nutrient requirements for flounder have been determined at moderate water temperatures $\left(18-22{ }^{\circ} \mathrm{C}\right)$ (Lee et al. 2000, 2002).

Olive flounder is the most important marine fish species in Korea with production exceeding $60 \%$ of annual fish production (Ministry of Maritime Affairs and Fisheries 2015). Olive flounder can be exposed to suboptimal temperatures during the culture period in Korea. Thus, knowledge on nutrient utilization in different water 
temperatures would be useful in optimizing dietary compositions or feeding conditions throughout the year for the growth of olive flounder. However, limited information is available on nutrient utilization in suboptimal water temperatures for this species. Therefore, the objective of this study was to determine the effects of taurine supplementation on growth, feed utilization, whole-body composition, innate immunity, and liver mRNA expression of IGF-1 of juvenile olive flounder at low water temperatures.

\section{Methods}

\section{Experimental diets}

Five experimental diets (Table 1) were formulated to contain taurine in fish meal-based diets at 0, 0.25, 0.5, 1.0, and 1.5\% (Control, T1, T2, T3, and T4) for juvenile olive flounder. The five diets were formulated to be isonitrogenous $(49.0 \%$ crude protein) and isocaloric (18.1 kcal $/ \mathrm{kg}$ diet). All dry ingredients were thoroughly mixed with 10-15\% double distilled water after addition of fish oil, pelleted through a pellet machine (SP-50, Gumgang Engineering, Daegu, Korea) at $6 \mathrm{~mm}$ in diameter, dried for $24 \mathrm{~h}$ and stored at $-20{ }^{\circ} \mathrm{C}$ until used.

Table 1 Formulation and chemical analysis of the five experimental diets for olive flounder (P. olivaceus) (\%, dry matter)

\begin{tabular}{llllll}
\hline Ingredients & \multicolumn{5}{l}{ Experimental diets } \\
\cline { 2 - 6 } & Control & $\mathrm{T} 1$ & $\mathrm{~T} 2$ & $\mathrm{~T} 3$ & $\mathrm{~T} 4$ \\
\hline Brown fish meal & 50.0 & 50.0 & 50.0 & 50.0 & 50.0 \\
Soybean meal & 5.00 & 5.00 & 5.00 & 5.00 & 5.00 \\
Corn gluten meal & 5.00 & 5.00 & 5.00 & 5.00 & 5.00 \\
Wheat flour & 27.0 & 27.0 & 27.0 & 27.0 & 27.0 \\
Fish oil & 8.00 & 8.00 & 8.00 & 8.00 & 8.00 \\
Starch & 1.00 & 1.00 & 1.00 & 1.00 & 1.00 \\
Mineral mix & 1.00 & 1.00 & 1.00 & 1.00 & 1.00 \\
Vitamin mix & 1.00 & 1.00 & 1.00 & 1.00 & 1.00 \\
Choline chloride & 0.50 & 0.50 & 0.50 & 0.50 & 0.50 \\
Glycine & 1.50 & 1.25 & 1.00 & 0.50 & 0.00 \\
Taurine & 0.00 & 0.25 & 0.50 & 1.00 & 1.50 \\
Chemical analysis (\%, dry & matter) & & & & \\
Moisture & 6.9 & 7.2 & 7.1 & 7.0 & 7.1 \\
Crude protein & 48.9 & 48.8 & 49.2 & 49.0 & 49.0 \\
Crude lipid & 13.2 & 13.0 & 13.1 & 13.0 & 13.2 \\
Crude ash & 8.0 & 8.1 & 8.1 & 8.2 & 8.2 \\
Taurine & 0.12 & 0.33 & 0.42 & 0.92 & 1.34 \\
\hline
\end{tabular}

${ }^{a}$ Mineral premix (g/kg mixture): $\mathrm{MgSO}_{4} .7 \mathrm{H}_{2} \mathrm{O}, 80.0 ; \mathrm{NaH}_{2} \mathrm{PO}_{4} .2 \mathrm{H}_{2} \mathrm{O}, 370.0 ; \mathrm{KCl}$, 130.0; Ferric citrate, 40.0; $\mathrm{ZnSO}_{4} .7 \mathrm{H}_{2} \mathrm{O}, 20.0$; Ca-lactate, 356.5; $\mathrm{CuCl}_{2}, 0.2 ; \mathrm{AlCl}_{3}$. $6 \mathrm{H}_{2} \mathrm{O}, 0.15 ; \mathrm{Na}_{2} \mathrm{Se}_{2} \mathrm{O}_{3}, 0.01 ; \mathrm{MnSO}_{4} . \mathrm{H}_{2} \mathrm{O}, 2.0 ; \mathrm{CoCl}_{2} .6 \mathrm{H}_{2} \mathrm{O}, 1.0$

${ }^{b}$ Vitamin premix (g/kg mixture): L-ascorbic acid, 121.2; DL-a tocopheryl acetate, 18.8; thiamin hydrochloride, 2.7; riboflavin, 9.1; pyridoxine hydrochloride, 1.8; niacin, 36.4; Ca-D-pantothenate, 12.7; myo-inositol, 181.8;D-biotin, 0.27; folic acid, 0.68; p-aminobezoic acid, 18.2; menadione, 1.8 ; retinyl acetate, 0.73 ; cholecalficerol, 0.003 ; cyanocobalamin, 0.003

\section{Fish and feeding trial}

Olive flounder juveniles were purchased from a private hatchery and transported to Marine and environmental Research Institute, Jeju National University, Jeju, South Korea. Fish were adapted to experimental conditions and facilities for 2 weeks. At the end of the acclimation period, total 525 fish (initial mean body weight, $19.5 \mathrm{~g}$ ) were randomly distributed into $15150 \mathrm{~L}$ capacity polyvinyl circular tanks with three replicate groups per diet treatment. The tanks were supplied with filtered seawater at a flow-rate of $3 \mathrm{~L} / \mathrm{min}$ and aeration to maintain enough dissolved oxygen. Each tank was designated as one of three replicates for a diet group. They were fed with the experimental diets to apparent satiation two times a day (08:30 and 17:00 h) for 10 weeks. Water temperature was naturally maintained at $16.4 \pm 0.36{ }^{\circ} \mathrm{C}$ during the whole duration. Growth measurement was carried out at every 2 weeks.

\section{Sample collections and analysis}

At the end of the feeding trial, all the fish in each tank were bulk-weighed and counted for calculation of weight gain (WG), specific growth rate (SGR), feed conversion ratio (FCR), protein efficiency ratio (PER), and survival. Four fish per tank (4 fish/tank, 12 fish/diet) were randomly captured $24 \mathrm{~h}$ after the last meal, anesthetized with 2-phenoxyethanol solution (200 $\mathrm{mg} / \mathrm{L})$, and blood samples were taken from the caudal vein with heparinized syringe for determination of hematocrit, hemoglobin, and nitro-blue-tetrazolium (NBT) activity. Then, plasma samples were separated by centrifugation at $5000 \times g$ for $10 \mathrm{~min}$ and stored at $-70{ }^{\circ} \mathrm{C}$ for determination of plasma chemicals and total immunoglobulin (Ig) level. Another set of blood samples (4 fish/tank, 12 fish/ diet) were taken using non-heparinized syringe and allowed to clot at room temperature for $30 \mathrm{~min}$. The serum was separated by centrifugation for $10 \mathrm{~min}$ at $5000 \times g$ and stored at $-70{ }^{\circ} \mathrm{C}$ for the analysis of nonspecific immune responses. Three intact fish per tank (3 fish/tank, 9 fish/diet) were randomly selected and kept at $-70{ }^{\circ} \mathrm{C}$ for whole-body composition analysis. Hematocrit was determined in four individual fish per tank by a microhematocrit method (Brown 1980). Hemoglobin, glucose, total protein and total cholesterol were determined in the same four fish by using the automated blood analyzer (SLIM, SEAC Inc., Florence, Italy). Oxidative radical production by phagocytes during respiratory burst was measured through the NBT activity assay described by Anderson and Siwicki (1995). Serum myeloperoxidase (MPO) activity was measured by Quade and Roth (1997). Superoxide dismutase (SOD) activity was measured by percentage reaction inhibition rate of enzyme with water soluble tetrazolium dye substrate and xanthine oxidase using a SOD assay kit 
(Sigma- aldrich, 19,160, St. Louis, USA) according to the manufacturer's instructions. Plasma total Ig level was determined by Siwicki and Anderson (1993). Serum lysozyme level was measured using turbidometric assay described by Hultmark et al. (1980). The serum antiprotease activity was measured by Ellis (1990) with slight modifications (Magnadottir et al. 1999). Moisture and ash content were analyzed by the standard procedures (AOAC 2005). Crude protein were measured by using automatic Kjeltec Analyzer Unit 2300 (FOSS, Hillerød, Sweden) and crude lipid was analyzed by Folch et al. (1957). Amino acid composition of the diets was determined using a Sycom S-433D automatic amino acid analyzer (Sykam, Eresing, Germany). Hydrolysis of the samples was performed in $6 \mathrm{~N} \mathrm{HCl}$ at $110{ }^{\circ} \mathrm{C}$ for $24 \mathrm{~h}$ under nitrogen atmosphere. Identification and quantification of each amino acid were achieved by comparing the retention times of the peaks with those of standards.

\section{Expression levels of liver IGF-1 mRNA}

Liver samples were taken from two fish per tank and total RNA was isolated using trizol reagent following the manufacturers' protocol. The quantity of the RNA was calculated using the absorbance at $260 \mathrm{~nm}$. The integrity and relative quantity of RNA were checked by gel electrophoresis. PrimeScript RT reagent Kit with gDNA Eraser (Perfect Real Time) (TaKaRa Code DRR047) was used to remove genomic DNA and reverse transcription. Levels of IGF-1 transcript were measured by real-time PCR (SYBR Green I), using 18S rRNA as a housekeeping gene. Primers for real-time PCR were designed based on the previously cloned sequence for IGF-1 (NCBI Genbank accession no: AF061278) and 18S rRNA (NCBI Genbank accession no: EF126037) in P. olivaceus. Relative expression ratio of IGF-1 was calculated based on the PCR efficiency (E) and the $\mathrm{Ct}$ of a sample versus the control (FM treatment) and expressed in comparison with the reference gene (18S rRNA); according to Pfaffl's mathematical model (Pfaffl 2001).

$$
\text { Ratio }=\left[\left(\mathrm{E}_{\mathrm{IGF}-1}\right)^{\Delta \mathrm{GF}(\text { control-sample })}\right] /\left[\left(\mathrm{E}_{\mathrm{actin}}\right)^{\mathrm{Ct}(\text { control-sample })}\right]
$$

\section{Statistical analysis}

The diets were assigned by a completely randomized design. Data were analyzed by one-way analysis of variance (ANOVA) in SPSS version 11.0 (SPSS Inc., Chicago, IL, USA). When ANOVA identifies differences among groups, the difference in means was made with Tukey's HSD multiple range test. Statistical significance was determined at $P<0.05$ for means of treatments. Percentage data were arcsine transformed before statistical analysis.

\section{Results}

Growth performance and feed utilization of juvenile olive flounders are shown in Table 2. All the taurinesupplemented groups showed numerically increased growth compared to the control even though it was not significant. The highest growth rate was found in fish fed T3 diet. However, feed utilization was significantly influenced by the taurine supplementation reducing FCR and increasing PER. FCR was significantly lower in fish fed all the taurine-supplemented diets than that of fish fed the control diet. Higher supplementation (T3 and T4) of taurine exhibited even significantly lower FCR than that of fish fed T1 and T2 diets. PER was significantly higher in fish fed T2, T3, and T4 diets compared to that of fish fed the control and $\mathrm{T} 1$ diets.

Hematological responses of fish fed the diets are shown in Table 3. Hematocrit and hemoglobin levels were significantly elevated by taurine supplementation. T3 group had the highest hematocrit and hemoglobin levels among all the groups. Total cholesterol level was significantly decreased in T4 group compared to the control group.

Results of non-specific immune response of fish fed the diets are shown in Table 4. All the immune parameters showed promising results in fish fed taurine-supplemented diets. All the taurine supplementation groups showed significantly higher NBT, MPO, Ig, and antiprotease activities compared to the control group. In SOD and lysozyme activities, significantly higher values were observed in taurine supplementation over $0.5 \%$ in diets except for T4 group. The highest NBT and lysozyme activities were shown in T3 group while the highest MPO, SOD, and antiprotease activities were in T2 and T3 groups. The highest Ig level was observed in T2 group.

Results of proximate compositions in whole-body samples are shown in Table 5. No significant effects were observed by the supplementation of taurine. Relative expression levels of IGF-1 mRNA is shown in Fig. 1. There was not much of an influence on expression, however, T4 group showed a significantly higher peak compared to other groups including the control group.

\section{Discussion}

Increased feed intake is a primary response of fish to increased water temperature (Bureau et al. 2002). Improved feed intake at high water temperature generally results in higher growth and feed efficiency (Kim et al. 2006). According to this phenomenon, reduced growth of fish in cold water is due to reduced feed intake. It was reported that fish fed an extruded feed at suboptimal water temperatures had relatively lower growth performance than that of fish fed raw fish or Oregon moist pellet (Satoh et al. 2003). This phenomenon is called winter syndrome. To solve the problem of winter syndrome, it is important to 
Table 2 Growth performance and feed utilization of olive flounder ( $P$. olivaceus, initial BW: $19.5 \mathrm{~g})$ fed the five experimental diets for 10 weeks. The diets were added with graded levels of taurine by $0,0.25,0.5,1.0$, and $1.5 \%$ (control, T1, T2, T3, and T4, respectively)

\begin{tabular}{|c|c|c|c|c|c|}
\hline & \multicolumn{5}{|c|}{ Experimental diets } \\
\hline & Control & $\mathrm{T} 1$ & $\mathrm{~T} 2$ & T3 & $\mathrm{T} 4$ \\
\hline$\overline{\mathrm{FBW}^{1}}$ & $38.1 \pm 0.66$ & $41.7 \pm 3.70$ & $39.8 \pm 7.89$ & $46.4 \pm 3.45$ & $44.6 \pm 5.10$ \\
\hline$W G^{2}$ & $96.5 \pm 3.39$ & $113 \pm 18.9$ & $103 \pm 40.3$ & $137 \pm 17.6$ & $128 \pm 26.0$ \\
\hline$S G R^{3}$ & $1.01 \pm 0.03$ & $1.13 \pm 0.13$ & $1.04 \pm 0.30$ & $1.29 \pm 0.11$ & $1.22 \pm 0.17$ \\
\hline $\mathrm{Fl}^{4}$ & $30.6 \pm 1.26$ & $35.1 \pm 5.85$ & $30.8 \pm 12.13$ & $33.3 \pm 4.04$ & $30.6 \pm 6.12$ \\
\hline $\mathrm{FCR}^{5}$ & $1.63 \pm 0.02^{a}$ & $1.58 \pm 0.00^{b}$ & $1.52 \pm 0.01^{c}$ & $1.24 \pm 0.01^{d}$ & $1.22 \pm 0.03^{d}$ \\
\hline $\mathrm{PER}^{6}$ & $1.32 \pm 0.01^{c}$ & $1.37 \pm 0.00^{c}$ & $1.42 \pm 0.01^{\mathrm{b}}$ & $1.74 \pm 0.01^{\mathrm{a}}$ & $1.77 \pm 0.04^{a}$ \\
\hline Survival (\%) & $60.0 \pm 5.71$ & $57.2 \pm 14.3$ & $63.8 \pm 13.2$ & $66.7 \pm 5.95$ & $57.5 \pm 15.9$ \\
\hline
\end{tabular}

Values are mean of triplicate groups and presented as mean \pm S.D. Values with different superscripts in the same row are significantly different $(P<0.05)$. The lack of superscript letter indicates no significant differences among treatments

${ }^{1}$ Final body weight $(\mathrm{g})$

${ }^{2}$ Weight gain $(\%)=100 \times($ final mean body weight - initial mean body weight)/initial mean body weight

${ }^{3}$ Specific growth rate $(\% /$ day $)=[($ In final body weight $-\ln$ initial body weight $) /$ days $] \times 100$

${ }^{4}$ Feed intake $\left(\mathrm{g} \mathrm{fish}^{-1}\right)=$ dry feed consumed/fish number

${ }^{5}$ Feed conversion ratio $=$ dry feed fed/wet weight gain

${ }^{6}$ Protein efficiency ratio $=$ wet weight gain/total protein given

improve feed intake or feed utilization to obtain better growth performance at low water temperature. Therefore, the present study was conducted to determine whether taurine supplement could improve feed intake of olive flounder at low water temperature.

It has been reported that taurine supplementation can improve growth performance of many fish species including olive flounder, parrot fish (Oplegnathus fasciatus), red seabream (Pagrus major) and yellow tail (Seriola quinqueradiata) (Kim et al. 2007; Matsunari et al. 2008; Takagi et al. 2008; Lim et al. 2013; Takagi et al. 2013; Hanini et al. 2013; Han et al. 2014; Khaoian et al. 2014). Kim et al. (2007) reported that the taurine requirement of olive flounder is $1.0 \%$ for juvenile and fingerling stages in optimal water temperature. Han et al. (2014) reported that taurine and glutamine supplementations can significantly improve growth, feed intake and FCR of olive flounder at optimal water temperature. However, studies on the effect of taurine supplementation at suboptimal water temperature are very limited. Water temperature varies depending on seasons for many regions. Fish shows normal behavior and best growth performance only in optimal water temperature because fish is a poikilotherm. In suboptimal water temperature, feed intake of fish usually decreases resulting in decreased growth performance. To solve the problem of winter syndrome, various methods using several feed stuffs such as enzyme treated fish meal, krill extract, or krill meal have been evaluated (Satoh 2003; Satoh et al. 2003). Satoh et al. (2003) have reported that daily growth rate and apparent protein digestibility of fish-fed diet with protease are worse than those fed with MP at low water temperature. However, there is no significant difference in feed efficiency between fish fed with diet treated with protease and those fed with MP diets (dry matter basis).

In the present study, growth of juvenile olive flounder was numerically increased by taurine supplementation resulting in improved FCR and PER, because feed intake was not different among all the groups. Therefore, feed

Table 3 Hematological parameters of olive flounder (P. olivaceus) fed the five experimental diets for 10 weeks. The diets were added with graded levels of taurine by $0,0.25,0.5,1.0$, and $1.5 \%$ (Control, $\mathrm{T} 1, \mathrm{~T} 2, \mathrm{~T} 3$, and $\mathrm{T} 4$, respectively)

\begin{tabular}{|c|c|c|c|c|c|}
\hline & Experimental & & & & \\
\hline & Control & $\mathrm{T} 1$ & $\mathrm{~T} 2$ & T3 & T4 \\
\hline$\overline{\mathrm{Ht}^{1}}$ & $15.8 \pm 1.58^{c}$ & $20.1 \pm 0.56^{\mathrm{b}}$ & $20.9 \pm 2.47^{\mathrm{ab}}$ & $24.2 \pm 0.51^{\mathrm{a}}$ & $22.8 \pm 0.95^{\mathrm{ab}}$ \\
\hline$H b^{2}$ & $2.81 \pm 0.17^{d}$ & $3.54 \pm 0.17^{b c}$ & $3.00 \pm 0.28^{c d}$ & $4.66 \pm 0.47^{\mathrm{a}}$ & $3.81 \pm 0.12^{b}$ \\
\hline Glucose $^{3}$ & $53.6 \pm 5.66$ & $48.9 \pm 2.87$ & $47.1 \pm 1.81$ & $56.3 \pm 6.69$ & $51.1 \pm 2.95$ \\
\hline Total protein ${ }^{4}$ & $3.86 \pm 0.26$ & $3.86 \pm 0.04$ & $4.16 \pm 0.26$ & $4.16 \pm 0.19$ & $3.97 \pm 0.25$ \\
\hline Total cholesterol $\left.\right|^{5}$ & $82.0 \pm 2.53^{\mathrm{a}}$ & $68.3 \pm 10.3^{\mathrm{ab}}$ & $71.6 \pm 5.76^{\mathrm{ab}}$ & $67.7 \pm 3.04^{\mathrm{ab}}$ & $67.0 \pm 0.76^{b}$ \\
\hline
\end{tabular}

Values are mean of triplicate groups and presented as mean \pm S.D. Values with different superscripts in the same row are significantly different $(P<0.05)$. The lack of superscript letter indicates no significant differences among treatments

${ }^{1}$ Hematocrit (\%)

${ }^{2}$ Hemoglobin $\left(\mathrm{g} \mathrm{dL}^{-1}\right)$

${ }^{3}$ Glucose $\left(\mathrm{mg} \mathrm{dL}^{-1}\right)$

${ }^{4}$ Total protein $\left(\mathrm{g} \mathrm{dL}^{-1}\right)$

${ }^{5}$ Total cholesterol $\left(\mathrm{mg} \mathrm{dL}^{-1}\right)$ 
Table 4 Non-specific immune response of olive flounder (P. olivaceus) fed the five experimental diets for 10 weeks. The diets were added with graded levels of taurine by $0,0.25,0.5,1.0$, and $1.5 \%$ (control, $\mathrm{T} 1, \mathrm{~T} 2, \mathrm{~T} 3$, and $\mathrm{T} 4$, respectively)

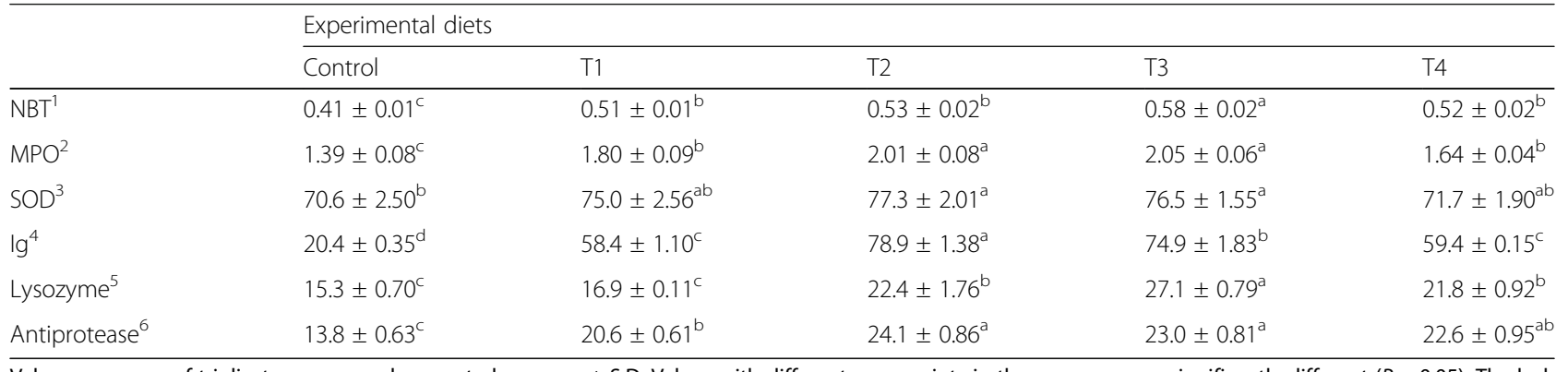

Values are mean of triplicate groups and presented as mean \pm S.D. Values with different superscripts in the same row are significantly different $(P<0.05)$. The lack of superscript letter indicates no significant differences among treatments

${ }^{1}$ Nitro blue tetrazolium activity

${ }^{2}$ Myeloperoxidase level

${ }^{3}$ Superoxide dismutase (\% inhibition)

${ }^{4}$ Total immunoglobulin $\left(\mathrm{mg} \mathrm{mL}^{-1}\right)$

${ }^{5}$ Lysozyme activity $\left(\mu \mathrm{g} \mathrm{mL}^{-1}\right)$

${ }^{6}$ Antiprotease (\% inhibition)

efficiency was positively influenced by taurine supplementation. Chatzifotis et al. (2008) reported that in a cold water condition, similar tendency to the current results was observed in common dentex (Dentex dentex)fed diet with taurine supplementation. Cook et al. (2003) investigated on winter syndrome of snapper (Lutjanus campechanus) and found similar results by dietary supplementation of $\beta$-glucan. Several studies in different fish species have reported similar results. Park et al. (2002) and Kim et al. (2007) reported that dietary taurine can significantly enhance the growth performance of juvenile Japanese flounder. The observations are similar to the results of juvenile yellowtail (Matsunari et al. 2005) and turbot (Scophthalmus maximus) (Qi et al. 2012). Growth rate and feed efficiency have been improved with taurine supplementation in European sea bass (Dicentrarchus labrax) (Brotons Martinez et al. 2004), rainbow trout (Gaylord et al. 2006), and black tiger shrimp (Penaeus monodon) (Shiau and Chou 1994).

Hematological parameters are also improved by the taurine supplementation. Blood parameters indicate the healthiness of fishes (Lemaire et al. 1991; Kader et al. 2010). Results of the present study showed that hematocrit and hemoglobin levels were significantly increased by taurine supplement. Similar results have been reported by Han et al. (2014) for olive flounder. High levels of cholesterol often indicate physiological disorders of fish (Eslamloo et al. 2012). In the present study, plasma cholesterol levels were high in fish fed the control diet. However, they were significantly reduced by taurine supplement. This might indicate that the fish fed the control diet were relatively under stresses. However, supplemental taurine feeding helped the fish recover at some degree, although such effect was not shown in survival rate. Non-specific immune response was the other major aspect we considered. Since the fish were in high stress conditions or challenging environment like in the suboptimal water temperature, if there was any effect of the dietary supplementation it could appear. Results of this study revealed that all the innate immune parameters of olive flounder could apparently be enhanced by dietary taurine supplement especially in a low water temperature condition. Fish in all groups fed taurine showed significantly higher innate immune responses than fish in the control group. Many studies have determined if taurine has positive effect on immunity of fish. Fang et al. (2002) reported that taurine can directly scavenge free radicals. Higuchi et al. (2012) also showed

Table 5 Whole-body composition of olive flounder (P. olivaceus) fed the five experimental diets for 10 weeks (\%, dry matter). The diets were added with graded levels of taurine by $0,0.25,0.5,1.0$, and $1.5 \%$ (control, T1, T2, T3, and T4, respectively)

\begin{tabular}{|c|c|c|c|c|c|}
\hline & \multicolumn{5}{|c|}{ Experimental diets } \\
\hline & Control & $\mathrm{T} 1$ & $\mathrm{~T} 2$ & T3 & T4 \\
\hline Dry matter & $75.4 \pm 0.53$ & $76.1 \pm 0.45$ & $75.4 \pm 0.68$ & $75.5 \pm 0.78$ & $75.9 \pm 0.20$ \\
\hline Protein & $66.4 \pm 0.74$ & $69.2 \pm 1.80$ & $67.7 \pm 1.55$ & $67.3 \pm 0.85$ & $67.9 \pm 0.45$ \\
\hline Lipid & $25.7 \pm 1.60$ & $23.9 \pm 1.92$ & $22.8 \pm 2.56$ & $27.7 \pm 1.58$ & $25.3 \pm 1.82$ \\
\hline Ash & $14.2 \pm 0.06$ & $11.8 \pm 2.85$ & $10.2 \pm 2.15$ & $12.5 \pm 0.83$ & $10.0 \pm 2.59$ \\
\hline
\end{tabular}

Values are mean of triplicate groups and presented as mean \pm S.D. Values with different superscripts in the same row are significantly different $(P<0.05)$. The lack of superscript letter indicates no significant differences among treatments 


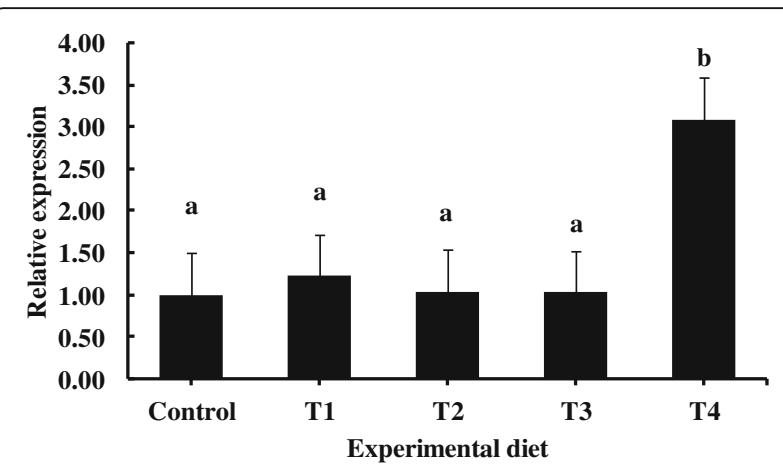

Fig. 1 Relative expression of IGF-1 in livers of olive flounder fed the five experimental diets for 10 weeks. The diets were added with graded levels of taurine by $0,0.25,0.5,1.0$, and $1.5 \%$ (control, T1, T2, T3, and T4, respectively). Values are mean of triplicate groups and presented as mean \pm S.D. Values in the same row having different superscript letters are significantly different $(P<0.05)$

elevated SOD levels in eels fed a taurine supplemented diet. Similarly, Han et al. (2014) reported higher SOD levels in olive flounder fed diets supplemented with taurine. Interestingly, the present study also showed that SOD and MPO levels were significantly increased in fish fed diets with taurine supplementation. Lysozyme is an important defense enzyme of innate immune system of fishes (Saurabh and Sahoo 2008) and has been used as a key parameter to evaluate non-specific defense ability (Zhou et al. 2006; Ren et al. 2007). Anti-protease is an enzyme which disables enzymes generated by a pathogen inside an organism (Magnadottir et al. 1999). Therefore, an increased level of anti-protease indicates an increase in immunity. In the present study, taurine-fed groups showed significant increment in both lysozyme and antiprotease activities. Similarly, Li et al. (2016) observed significant increase in lysozyme activity of yellow catfish (Pelteobagrus fulvidraco). Therefore, these results indicate that taurine not only can improve health and immunity of mammals (Kingston et al. 2004; Gupta et al. 2006), but also can improve the health and innate immunity of fish. IGF-1 mRNA expression was assessed in this study as a new parameter to determine whether taurine supplementation might have effect on gene expression. Interestingly, our results showed that IGF-1 mRNA expression level was significantly increased by $1.5 \%$ taurine supplementation. Some studies have been conducted to determine whether taurine supplementation could affect fish at gene expression level (Kingston et al. 2004; Gupta et al. 2006). The function of IGF-1 in fish is similar to that in human or mammals, and IGF-1 can only exert nutritional regulation in the liver of fish (Duan et al. 1994; Duan 1998). Therefore, only liver tissue was analyzed in this study for IGF-1 expression. Niu and Le Bail (1993) reported that IGF-1 level is significantly decreased in fasted rainbow trout. The elevated peak of IGF-1 in the present study suggests that IGF-1 gene can be up-regulated by the taurine supplementation in diets for olive flounder. Optimum level of taurine supplementation in fish diets has already been elucidated in previous studies for several fish species, such as cobia (Rachycentron canadum) (Kousoulaki et al. 2009), Japanese flounder (Kim et al. 2003, 2007, 2008), red seabream (Takagi et al. 2010), and sea bass (Brotons Martinez et al. 2004). According to these studies, the optimum level of taurine supplementation depends on fish species and growth stage of fish. Salze and Davis (2015) have reported that different taurine supplementation levels are needed in different fish species with different growth stages.

\section{Conclusions}

This study suggests that taurine supplementation is effective in improving growth performance, feed efficiencies and innate immunity of juvenile olive flounder in low water temperature season. The suggested taurine supplementation level would be between 1.0 and 1.5\% (analyzed levels; $0.9-1.3 \%$ in diets) in a fish meal-based diet for olive flounder in suboptimal water temperature condition.

\section{Abbreviations \\ FBW: Final body weight; FCR: Feed conversion ratio; Hb: Hemoglobin; Ht: Hematocrit; Ig: Immunoglobulin; IGF-1: Insulin-like growth factor 1; MPO: Myeloperoxidase; NBT: Nitro blue tetrazolium; PER: Protein efficiency ratio; SGR: Specific growth rate; SOD: Superoxide dismutase; WG: Weight gain \\ Acknowledgements \\ This research was supported by the 2017 scientific promotion program funded by Jeju National University. \\ Funding \\ This study was funded by Jeju National University under the 2017 scientific promotion program.}

\section{Availability of data and materials}

All datasets analyzed in this study are available from the corresponding author on reasonable request.

\section{Authors' contributions}

JMK and GHTM conducted the feeding trial, analysis, and manuscript preparation. GLBEG, CL, and MGK participated in the analyses of samples and supporting the manuscript preparation. BJL and JDK read and revised the manuscript. KJ organized, designed, and completed the manuscript. All authors have read and approved the final manuscript.

\section{Ethics approval and consent to participate}

Experimental protocols followed the guidelines of the Animal Care and Use Committee of Jeju National University.

Competing interests

The authors declare that they have no competing interests.

\section{Publisher's Note}

Springer Nature remains neutral with regard to jurisdictional claims in published maps and institutional affiliations.

\section{Author details}

${ }^{1}$ Sajodongaone, 873, Deokpyeong Ro, Sunseong-myeon, Dangjin-Si,

Chungcheongnam Do 31759, South Korea. ${ }^{2}$ Department of Marine Life 
Sciences, Jeju National University, Jeju 63243, South Korea. ${ }^{3}$ Aquafeed Research Center, National Institute of Fisheries Science, Pohang 37517, South Korea. ${ }^{4}$ College of Animal Life Science, Kangwon National University, Chuncheon 24341, South Korea.

\section{Received: 19 June 2017 Accepted: 16 August 2017}

Published online: 06 September 2017

\section{References}

Anderson DP, Siwicki AK. Basic hematology and serology for fish health programs. Manila, Philippines: Leetown Science Center; 1995. p. 185-202.

AOAC. Official Methods of Analysis. $18^{\text {th }}$ edition. Association of Official Analytical Chemists: Arlington; 2005.

Brotons Martinez J, Chatzifotis S, Divanach P, Takeuchi T. Effect of dietary taurine supplementation on growth performance and feed selection of sea bass Dicentrarchus labrax fry fed with demand-feeders. Fish Sci. 2004;70:74-9.

Brown BA. Routine hematology procedures, in: Brown, B.A. (Ed.), Hematology, Principles and Procedures, Lea and Febiger. Philadelphia; 1980. p.71-112.

Bureau DP, Kaushik SJ, Cho CY. Bioenergetics. In: Fish Nutrition. 3rd ed. USA: Elsevier Science; 2002. p. 2-61.

Carr WES. Chemical stimulation of feeding behavior. In: Hara TJ, editor. Chemoreception in fishes. Amsterdam: Elsevier; 1982. p. 259-73.

Chatzifotis S, Polemitou I, Divanach P, Antonopoulou E. Effect of dietary taurine supplementation on growth performance and bile salt activated lipase activity of common dentex, Dentex dentex, fed a fish meal/soy protein concentrate-based diet. Aquaculture. 2008;275:201-8.

Cook MT, Hayball PJ, Hutchinson W, Nowak BF, Hayball JD. Administration of a commercial immunostimulant preparation, EcoActiva ${ }^{\mathrm{TM}}$ as a feed supplement enhances macrophage respiratory burst and the growth rate of snapper (Pagrus auratus, Sparidae (Bloch and Schneider)) in winter. Fish Shellfish Immunol. 2003;14:333-45.

De la Rosa J, Stipanuk MH. Evidence for the rate-limiting role of cysteinesulfinate decarboxylase activity in taurine biosynthesis in vivo. Comp Biochem Physiol. 1985;81:565-71.

Doving KB, Selset R, Thommesen G. Olfactory sensitivity to bile acids in salmonid fishes. Acta Physiol. 1980;108:123-31.

Duan C. Nutritional and developmental regulation of insulin-like growth factors in fish. J Nutr. 1998;128:3056-145.

Duan C, Duguay SJ, Swanson P, Dickhoff WW, Plisetskaya EM. Tissue-specific expression of insulin-like growth factor I messenger ribonucleic acids in salmonids: developmental, hormonal, and nutritional regulation. Perspect Comp Endocrinol. 1994:365-72.

Ellis AE. Serum antiproteases in fish. In: Stolen JS, Fletcher TC, Anderson DP, Roberson BS, editors. Techniques in fish immunology. NJ: SOS Publications; 1990. p. 95-9.

Eslamloo K, Falahatkar B, Yokoyama S. Effects of dietary bovine lactoferrin on growth, physiological performance, iron metabolism and non-specific immune responses of Siberian sturgeon Acipenser baeri. Fish Shellfish Immunol. 2012;32:976-85.

Fang YZ, Yang S, Wu GY. Free radicals, antioxidants, and nutrition. Nutrition. 2002; 18:872-9.

Folch J, Lees M, Sloane Stanley GH. A simple method for the isolation and purification of total lipids from animal tissues. J Biol Chem. 1957;226:497-509.

Gaylord TG, Teague AM, Barrows FT. Taurine supplementation of all-plant protein diets for rainbow trout (Oncorhynchus mykiss). J World Aquac Soc. 2006;37: 509-17.

Gupta RC, Seki Y, Yosida J. Role of taurine in spinal cord injury. Curr Neurovasc Res. 2006;3:225-35.

Han Y, Koshio S, Jiang Z, Ren T, Ishikawa M, Yokoyama S, Gao J. Interactive effects of dietary taurine and glutamine on growth performance, blood parameters and oxidative status of Japanese flounder Paralichthys olivaceus. Aquaculture. 2014;434:348-54.

Hanini I, Sarker MSA, Satoh S, Haga Y, Corneillie S, Ohkuma T, Nakayama H. Effects of Taurine, Phytase and Enzyme Complex Supplementation to Low Fish Meal Diets on Growth of Juvenile Red Sea Bream Pagrus major. Aquaculture Sci. 2013;61:367-75.

Hara TJ, Macdonald S, Evans RE, Marui T, Arai S. In: JD MC, Arnold GP, Dodson JJ, Neill WH, editors. Morpholine, bile acids and skin mucus as possible chemical cues in salmonid homing: electrophysiological re-evaluation. New York: Mechanisms of Migration in Fishes; 1984. p. 363-78.
Higuchi M, Celino FT, Shimizu-Yamaguchi S, Miura C, Miura T. Taurine plays an important role in the protection of spermatogonia from oxidative stress. Amino Acids. 2012;43:2359-69.

Hultmark D, Steiner H, Rasmuson T, Boman HG. Insect immunity. Purification and properties of three inducible bactericidal proteins from hemolymph of immunized pupae of Hyalophora cecropia. FEBS J. 1980;106:7-16.

I wata N, Kikuchi K, Honda H, Kiyono M, Kurokura H. Effects of temperature on the growth of Japanese flounder. Fish Sci. 1994;60:527-31.

Kader MA, Koshio S, Ishikawa M, Yokoyama S, Bulbul M. Supplemental effects of some crude ingredients in improving nutritive values of low fishmeal diets for red sea bream, Pagrus major. Aquaculture. 2010;308:136-44.

Khaoian P, Ogita H, Watanabe H, Nishioka M, Kanosue F, Nguyen HP, Fukada H, Masumoto T. Effects of Taurine Supplementation to Low Fish Meal Practical Diet on Growth, Tissue Taurine Content and Taste of 1 Year Yellowtail Seriola quinqueradiata. Aquaculture Sci. 2014;62:415-23.

Kim KD, Kim KM, Kim KW, Kang YJ, Lee SM. Influence of lipid level and supplemental lecithin in diet on growth, feed utilization and body composition of juvenile flounder (Paralichthys olivaceus) in suboptimal water temperatures. Aquaculture. 2006;251:484-90.

Kim SK, Matsunari H, Nomura K, Tanaka H, Yokoyama M, Murata Y, Ishihara K, Takeuchi T. Effect of dietary taurine and lipid contents on conjugated bile acid composition and growth performance of juvenile Japanese flounder Paralichthys olivaceus. Fish Sci. 2008;74:875-81.

Kim SK, Matsunari H, Takeuchi T, Yokoyama M, Murata Y, Ishihara K. Effect of different dietary taurine levels on the conjugated bile acid composition and growth performance of juvenile and fingerling Japanese flounder Paralichthys olivaceus. Aquaculture. 2007;273:595-601.

Kim SK, Takeuchi T, Yokoyama M, Murata Y. Effect of dietary supplementation with taurine, $\beta$-alanine and GABA on the growth of juvenile and fingerling Japanese flounder Paralichthys olivaceus. Fish Sci. 2003;69:242-8.

Kim SK, Takeuchi T, Yokoyama M, Murata Y, Kaneniwa M, Sakakura Y. Effect of dietary taurine levels on growth and feeding behavior of juvenile Japanese flounder Paralichthys olivaceus. Aquaculture. 2005;250:765-74.

Kingston R, Kelly CJ, Murray P. The therapeutic role of taurine in ischaemiareperfusion injury. Curr Pharm Des. 2004;10:2401-10.

Kousoulaki K, Albrektsen S, Langmyhr E, Olsen HJ, Campbell P, Aksnes A. The water soluble fraction in fish meal (stickwater) stimulates growth in Atlantic salmon (Salmo salar L.) given high plant protein diets. Aquaculture. 2009;289: 74-83.

Lee SM, Cho SH, Kim KD. Effects of dietary protein and energy levels on growth and body composition of juvenile flounder Paralichthys olivaceus. J World Aquac Soc. 2000;31:306-15.

Lee SM, Park CS, Bang IC. Dietary protein requirement of young Japanese flounder Paralichthys olivaceus fed isocaloric diets. Fish Sci. 2002;68:158-64.

Lemaire P, Drai P, Mathieu A, Lemaire S, Carriere S, Giudicelli J, Lafaurie M. Changes with different diets in plasma enzymes (GOT, GPT, LDH, ALP) and plasma lipids (cholesterol, triglycerides) of sea-bass (Dicentrarchus labrax). Aquaculture. 1991;93:63-75.

Li M, Lai H, Li Q, Gong S, Wang R. Effects of dietary taurine on growth, immunity and hyperammonemia in juvenile yellow catfish Pelteobagrus fulvidraco fed all-plant protein diets. Aquaculture. 2016;450:349-55.

Lim SJ, Oh DH, Khosravi S, Cha JH, Park SH, Kim KW, Lee KJ. Taurine is an essential nutrient for juvenile parrot fish Oplegnathus fasciatus. Aquaculture, 414-415. 2013:274-9.

Magnadottir B, Jonsdottir H, Helgason S, Bjornsson B, Jon T, Pilstroil L. Humoral immune parameters in Atlantic cod (Gadus morhua L): I. the effects of environmental temperature. Comp Biochem Physiol. 1999;122:173-80.

Matsunari H, Furuita H, Yamamoto T, Kim SK, Sakakura Y, Takeuchi T. Effect of dietary taurine and cystine on growth performance of juvenile red sea bream Pagrus major. Aquaculture. 2008;274:142-7.

Matsunari H, Takeuchi T, Takahashi M, Mushiake K. Effect of dietary taurine supplementation on growth performance of yellowtail juveniles Seriola quinqueradiata. Fish Sci. 2005;71:1131-5.

Ministry of Maritime Affairs and Fisheries. Aquaculture Statistic from Ministry of Maritime Affairs and Fisheries of Korea. 2015.

Niu PD, Le Bail PY. Presence of insulin-like growth factor binding protein (IGF-BP) in rainbow trout (Oncorhynchus mykiss) serum. J Exp Zool. 1993;265:627-36.

Oja SS, Kontro P. Taurine. In: Metabolism in the Nervous System. US: Springer; 1983. p. 501-33.

Olsen RE, Ringn E. The influence of temperature on the apparent nutrient and fatty acid digestibility of Arctic charr, Salvelinus alpinus L. Aquac Res. 1998;29:695-701. 
Park GS, Takeuchi T, Yokoyama M, Seikal T. Optimal dietary taurine level for growth of juvenile Japanese flounder Paralichthys olivaceus. Fish Sci. 2002;68:824-9.

Peres H, Oliva-Teles A. Influence of temperature on protein utilization in juvenile European sea bass (Dicentrarchus labrax). Aquaculture. 1999;170:337-48.

Petrosian AM, Haroutounian JE. Taurine as a universal carrier of lipid soluble vitamins: a hypothesis. Amino Acids. 2000;19:409-21.

Pfaffl MW. A new mathematical model for relative quantification in real-time RTPCR. Nucleic Acids Res. 2001;29:e45.

Qi G, Ai Q, Mai K, Xu W, Liufu Z, Yun B, Zhou H. Effects of dietary taurine supplementation to a casein-based diet on growth performance and taurine distribution in two sizes of juvenile turbot (Scophthalmus maximus L.). Aquaculture. 2012;358:122-8.

Quade MJ, Roth JA. A rapid, direct assay to measure degranulation of bovine neutrophil primary granules. Vet Immunol Immunop. 1997;58:239-48.

Ren T, Koshio S, Ishikawa M, Yokoyama S, Micheal FR, Uyan O, Tung HT. Influence of dietary vitamin $C$ and bovine lactoferrin on blood chemistry and nonspecific immune responses of Japanese eel, Anguilla japonica. Aquaculture. 2007;267:31-37.

Salze GP, Davis DA. Taurine: a critical nutrient for future fish feeds. Aquaculture. 2015:437:215-29.

Satoh Kl. Effects of supplement with krill extract and krill meal to diet on the growth performance and protein digestibility of yellowtail during low water temperature. Aquaculture Sci. 2003;51:93-9.

Satoh Kl, Maita M, Wakatsuki A, Matsuda S. Growth and feed efficiency of adult yellowtail fed extruded pellet diets with two lipid levels and raw-fish diets. Aquaculture Sci. 2003:51:343-8.

Saurabh S, Sahoo PK. Lysozyme: an important defence molecule of fish innate immune system. Aquac Res. 2008;39:223-39.

Schaffer S, Takahashi K, Azuma J. Role of osmoregulation in the actions of taurine. Amino Acids. 2000;19:527-46.

Shiau SY, Chou BS. Grass shrimp, Penaeus monodon, growth as influenced by dietary taurine supplementation. Comp Biochem Phys A. 1994;108:137-42.

Siwicki AK, Anderson DP. Nonspecific defense mechanisms assay in fish: II. Potential killing activity of neutrophils and macrophages, lysozyme activity in serum and organs and total immunoglobulin level in serum. In: Disease Diagnosis and Prevention Methods. FAO-project GCP/INT/JPA, IFI Olsztyn, Poland;1993. p.105-112.

Takagi S, Murata H, Goto T, Endo M, Yamashita H, Ukawa M. Taurine is an essential nutrient for yellowtail Seriola quinqueradiata fed non-fish meal diets based on soy protein concentrate. Aquaculture. 2008;280:198-205.

Takagi S, Murata H, Goto T, Hatate H, Endo M, Yamashita H, Miyatake H, Ukawa M. Necessity of dietary taurine supplementation for preventing green liver symptom and improving growth performance in yearling red sea bream Pagrus major fed nonfishmeal diets based on soy protein concentrate. Fish Sci. 2010;76:119.

Takagi S, Murata H, Goto T, Hatate H, Yamashita H, Takano A, Ukawa M. Longterm Feeding of the Yellowtal Seriola quinqueradiata with Soy Protein Concentrate-based Non-fishmeal Diet Supplemented with Taurine. Aquaculture Sci. 2013;61:349-58.

Takeuchi T, Park GS, Seikai T, Yokoyama M. Taurine content in Japanese flounder Paralichthys olivaceus and red sea bream Pagrus major T. \& S. during the period of seed production. Aquac Res. 2001;32:244-8.

Van Waarde A. Biochemistry of non-protein nitrogeneous compounds in fish including the use of amino acids for anaerobic energy production. Comp Biochem Physiol. 1988;91:207-28.

Wright CE, Talan HH, Lin YY, Coaull GE. Taurine: biological update. Annu Rev Biochem. 1986:55:427-53

Yokoyama M, Takeuchi T, Park GS, Nakazoe J. Hepatic cysteinesulphinate decarboxylase activity in fish. Aquac Res. 2001;32:216-20.

Zhou J, Song XL, Huang J, Wang XH. Effects of dietary supplementation of A3apeptidoglycan on innate immune responses and defense activity of Japanese flounder (Paralichthys olivaceus). Aquaculture. 2006;251:172-81.

\section{Submit your next manuscript to BioMed Central and we will help you at every step:}

- We accept pre-submission inquiries

- Our selector tool helps you to find the most relevant journal

- We provide round the clock customer support

- Convenient online submission

- Thorough peer review

- Inclusion in PubMed and all major indexing services

- Maximum visibility for your research

Submit your manuscript at www.biomedcentral.com/submit
Biomed Central 